\title{
Telecommunications Policy Reform in Turkey
}

\author{
Erkan Akdemir ${ }^{1}$,Erdem Başç ${ }^{2}$ and Sübidey Togan ${ }^{3}$ \\ ${ }^{1}$ Cisco, ${ }^{2}$ Central Bank of Turkey and ${ }^{3}$ Bilkent University
}

\section{INTRODUCTION}

\begin{abstract}
$\mathfrak{T}$ HIS paper studies the economic effects of liberalisation in the telecommunications sector on the Turkish economy. Since Turkey is trying to liberalise the telecommunications sector by following the EU approach to liberalisation, we consider in Section 2 the regulatory regimes in the telecommunications sectors of the EU and Turkey. In Section 3 we make use of the empirical studies on the linkages between regulatory regimes and telecommunications prices, determine the ad valorem equivalent of barriers to the telecommunications services sector in Turkey, and derive estimates of the welfare effects of adopting the EU rules and regulations in the Turkish telecommunications sector. Section 4 concludes.
\end{abstract}

\section{THE REGULATORY FRAMEWORK IN THE EU AND TURKEY}

Since its inception in the mid-1980s, EU telecommunications policy has focused on two main objectives: economic efficiency and guarantee of universal service. In 1987 the Commission issued a Green Paper which set out a Communitywide programme for action in the telecommunications sector in pursuit of these objectives. The achievement of these aims has been pursued through the application of a set of complementary principles: market liberalisation and harmonisation of conditions for a common regulatory framework.

The authors are grateful to an anonymous referee on a previous draft of this paper for valuable comments. The paper is an extension of the work undertaken within the context of the FEMISE project 'Impact of Liberalization of Trade in Services: Banking, Telecommunications and Maritime Transport in Egypt, Morocco, Tunisia and Turkey' (FEM22-02). The financial support from the Forum Euro-Mediterranée des Instituts Economiques (FEMISE), supported by the European Commission, is greatly appreciated. The views expressed are those of the authors and therefore in no way reflect the official opinion of the Commission. 
Following publication of the Green Paper the Commission adopted the Terminal Equipment Directive 1988, ${ }^{1}$ which obliged Member States to remove special or exclusive rights relating to the importation, marketing, connection, bringing into service and maintenance of telecommunication terminal equipment. The Commission Directive 90/388/EEC (Services Directive) initiated the opening to competition of the telecommunications services market by providing for the removal and exclusive rights granted by Member States to Telecommunications Organisations for the supply of value-added services by the end of 1990 and data services by 1 January, 1993. Remaining monopolies within the telecommunications services, which continued as 'reserved services' after the implementation of the Services Directive were lifted through the adoption of Satellite Directive (94/46/EC), Cable Directive (95/51/EC) and Mobile Directive (96/2/EC). Thereafter, the Commission adopted the Full Competition Directive (96/19/EC) in February 1996, taking the final step in the liberalisation of the sector. The latter Directive called on Member States to take the necessary steps in order to ensure that markets were fully open by 1 January, 1998. Since 1998, the EU has fully competitive telecommunications markets in all Member States but five. Portugal, Spain, Greece, Ireland and Luxembourg had derogations. As recently as 2002 the EU introduced the Framework, Authorisation, Access, and Universal Service Directives and Local Loop Unbundling Regulation, the purpose of which is to provide a common regulatory framework and competition principles and practices for the electronic communications sector in the EU comprising telecommunications, media and information technology services. ${ }^{2}$

\footnotetext{
${ }^{1}$ Commission Directive 88/301/EEC of 16 May, 1988, on competition in the markets in telecommunications terminal equipment, OJ 1988 L 131/73.

2 The Framework Directive (2002/21/EC) emphasises the independence of the national regulatory authority (NRA) which has to be guaranteed by member states, the right of appeal against NRA decisions, mechanisms for ex-ante regulation to be imposed on significant market power, market definition and market analysis procedures, and NRA's duties to resolve disputes within four months when negotiations on access and interconnections fail. It applies to all telecommunications networks (fixed or wireless) as well as broadcast networks (terrestrial, satellite and cable), so that equivalent rules will apply to all these networks. On the other hand, the Authorisation Directive (2002/20/EC) abolishes individual licensing and moves to a system of general authorisation according to which older licensing schemes for different telecommunications services, i.e. public voice and data providers, and facilities-based and resale providers have been removed. The access to the network elements and associated facilities is regulated by the Access Directive (2002/19/EC) and the Unbundled Access to the Local Loop Regulation (No. 2887/2000). While the Access Directive establishes the rights and obligations of operators regarding interconnections and/or access, and defines the objectives of and the procedures for the NRAs on a mandatory access scheme, Regulation No. 2887/2000 asserts that notified operators are obliged to meet reasonable requests for unbundled access to the local loop under transparent, fair and non-discriminatory conditions. Finally, universal service is defined in the 2002 acquis as the provision of a defined minimum set of services to all end-users at affordable prices. The EU sees universal service as an obligation on its Member States. However, care is taken not to distort the market mechanism while safeguarding the public interest.
} 


\section{ERKAN AKDEMIR, ERDEM BAŞÇI AND SÜBIDEY TOGAN}

On the other hand, the telecommunication services in Turkey were provided until 1994 by the state-owned company PTT, a national monopoly providing postal and telecommunications services. In 1995 Türk Telekom (TT) was legally established as a state economic enterprise, which is a national monopoly with exclusive rights to all fixed-line voice operations and all telecommunication infrastructures but mobile. ${ }^{3}$ In addition, cable services were provided by TT, which was also responsible for the radio and television transmitters. Recognising that competition is the best way to ensure efficient operation and sufficient technological innovation to keep up with the pace of global change, and that regulation is vital, Turkey decided to liberalise the telecommunications sector during the 1990s.

During 2000 the Turkish Parliament approved the legislation to reform the telecommunications sector. ${ }^{4}$ The new legislation initiated the process of deregulating the sector over the medium term. Competition for fixed-line services was to be introduced over time. According to the Bill, fixed-line liberalisation was supposed to occur by the end of 2003, and at the time of liberalisation mobile and value-added services were to be made truly competitive. A regulatory authority called the Telecommunications Authority (TA) was established in 2000. Concessions and licences were to be issued by the Ministry of Transport, while preparation of the documents was delegated to the regulator. Pricing would be a function of the regulatory body. After the enactment of the legislation the new regulatory board has been appointed and the decree setting up the authority was published in August 2000. The legislation further transformed TT into an independent jointstock company subject to all provisions of the Turkish Commercial Code in order to open its capital to private participation. On 12 May, 2001, the Turkish Parliament passed the new Telecommunications Law, which aims to end state monopoly on land-line telecom services by privatising most of TT before 31 December, 2003 . $^{5}$ The expiry date for TT's monopoly was set as the date when the publicly owned shares of TT would fall under 50 per cent. The government is to keep a golden share. According to the law 99 per cent of all outstanding shares could be sold to both Turkish and foreign investors, but the share of foreigners could not exceed 45 per cent of the outstanding shares. In 2004, foreign ownership limitation was promulgated by the law numbered 5189. Following the Council of Minister Decree dated 15 October, 2004, no. 7931, 55 per cent of TT shares was sold to the highest bidder, Oger Telecoms Joint Venture Group, on 1 July, 2005.

With the latest amendments to the Telecommunications Law concessions and licences are to be issued by the TA. The main tasks and responsibilities of the TA

\footnotetext{
${ }^{3}$ Between 1994 and 1998 mobile services were provided by the private companies Turkcell and Telsim under the provisions of the Revenue Sharing Contract signed individually between those undertakings and TT.

${ }^{4}$ Law numbered 4502.

${ }^{5}$ Law numbered 4673.
} 
consist of licensing operators in the telecommunications sector, setting administrative, financial and technical regulations, performing a follow-up function of these regulations, issuing technical standards and testing the equipment in accordance with these standards, and implementing administrative and financial measures to those who break the rules and regulations. During the last few years, the TA has issued new service licences in addition to the already granted concessions and licences. ${ }^{6}$ But liberalisation of the telecommunications sector requires that licences are issued not only to service providers, but also to network providers. In fixedline services TT as of 2006 is still a monopoly. After the privatisation of TT the new company is still a monopoly unless additional licences are issued to other network providers. Finally, it should be noted that the Turkish licensing regime is still not parallel to the EU authorisation regulation, since all telecommunication services and infrastructures are subject to a licence, including services which do not need scare resources like frequency and numbering.

The TA published the tariff regulation in August 2001, according to which tariffs will be cost-based, and a 'price cap' formula will be applied for the services supplied by TT. In addition, TA issued two crucial regulations regarding the access regime, namely the 'Regulation on Access and Interconnection' in May 2003 and the 'Regulation Regarding Local Loop Unbundling' in July 2004. The Communiqué entered into force by July 2005. To implement the Ordinance on Access and Interconnection, the TA approved 'Principles and Procedures on Accounting Separation and Cost Accounting' in February 2004 with a transition period of two years so that operators having SMP can establish an applicable accounting separation system in the meantime. The Communique regulating administrative, technical and legal issues on collocation and facility sharing was published in the Official Gazette on 31 December, 2003. Apart from the above-mentioned regulations, the TA issued implementing regulations on the designation of SMP, numbering, personal data protection and privacy as well as on 'Radio and Telecommunications Terminal Equipment', and drafted its framework regulation on rights of way and consumer rights. On the other hand, a new legislation (no. 5369) was enacted in June 2005 framing the universal services obligations. According to the current legislative framework, TT is obliged to provide payphone, emergency

\footnotetext{
${ }^{6}$ Twenty-three licences for Satellite Telecommunication Services, 3 for Satellite Platform Services, 5 for GMPCS Mobile Telephony Services, 14 for Data Transmission Services over Fixed Lines, 91 for Internet Service Providers and 43 licences for Long Distance and International Telephony Services have been granted so far. In addition, TT was authorised under its Authorisation Agreement with the Authority to supply many different services such as public switched telephone network (PSTN), payphones, cable TV, ISDN, ADSL, leased circuits, Internet service provision, etc., and to operate the telecommunications infrastructure. On the other hand, the three GSM operators provide data services such as SMS, WAP, GPRS and MMS over intelligent networks, and services with added value such as geographical information, special invoicing, establishing virtual user platform, introduction of different structures for schedules of charge and options, voice-mail and GSM-mail.
} 


\section{ERKAN AKDEMIR, ERDEM BAŞÇI AND SÜBIDEY TOGAN}

call and directory services as a universal service. But there is not any obligatory requirement for other operators than TT and there is no funding mechanism for net costs of services provided by TT.

\section{WELFARE EFFECTS}

In the following, when considering the welfare effects of integration, we abstract from explicit consideration of problems of implementation, and assume that once the acquis is adopted liberalisation of the sector will be achieved. This is a simplification. But through this simplification the problem can be analysed in two steps. First we study the linkages between regulatory regimes and performance indicators. Then we turn to the analysis of the effects of integration in the telecommunications sector on the Turkish economy. The rest of the section is organised as follows. While the first subsection is on the relation between regulatory regimes and performance indicators, the second subsection considers the restrictions prevailing in the Turkish telecommunications sector during 2005. Finally, the third subsection analyses the welfare effects of integration in the Turkish economy.

\section{a. Regulatory Regimes and Performance Indicators: Review of the Literature}

Table 1 provides an overview of the market and regulatory environment in selected EU countries and Turkey as they have prevailed in the telecommunications sector during the latter half of the 1990s. The table reveals that entry conditions in trunk (domestic long distance), international and mobile services in Finland, the Netherlands and the United Kingdom had been substantially relaxed, while Turkey maintained legal monopoly conditions in trunk and international services. While full-entry liberalisation in the UK occurred during the mid-1980s it was attained in the Netherlands and Finland during the 1990s, and it was attained in Turkey only by 2004 . While the EU countries did not impose any restrictions on the FDI flows, restrictions were widespread in Turkey. Moreover, experience shows that in the transition from monopoly to competition the incumbent public telecommunications operator (PTO) often maintained a competitive advantage which could be exploited to preserve a dominant position. While by 1998 the shares of the largest operators were relatively low in the case of Britain, a firstmover country, the respective shares were higher in the case of late movers such as the Netherlands.

A similar pattern is observed in the case of public ownership. While the sector was transferred completely to the private sector by 1998 in the UK, government ownership in the sector amounted to 78.8 per cent in the case of Finland, 43.8 per cent in the case of the Netherlands and 100 per cent in the case of Turkey. Furthermore, the table shows that price regulation is still widespread in the EU 
TABLE 1

Country Data on European and Turkish Telecommunications, 1998

\begin{tabular}{|c|c|c|c|c|}
\hline & Finland & Netherlands & United Kingdom & Turkey \\
\hline \multicolumn{5}{|c|}{ Regulation of Entry and Foreign Investment } \\
\hline \multicolumn{5}{|c|}{ Legal conditions of entry } \\
\hline International & Open & Open & Open & Licence, 1 firm \\
\hline Mobile & Limited by spectrum & Limited by spectrum & Limited by spectrum & Limited by spectrum \\
\hline \multicolumn{5}{|l|}{ Year of liberalisation } \\
\hline Trunk & 1993 & 1997 & 1985 & 2004 \\
\hline International & 1993 & 1997 & 1986 & 2004 \\
\hline Mobile & $<1992$ & 1995 & 1984 & $1997 / 98$ \\
\hline \multicolumn{5}{|l|}{ Foreign investment } \\
\hline Number of competitors & - & - & 7 & 4 \\
\hline FDI restrictions & No & No & No & Yes \\
\hline Restrictions concerning PTO & Yes & Yes & Yes & State control \\
\hline \multicolumn{5}{|l|}{ Market Structure } \\
\hline Basic voice telephony: trunk & 20 & 3 & $>20$ & 1 \\
\hline Number of licence holders & 55 & 80 & 76 & 100 \\
\hline Share of largest operator & 40 & & 10 & 0 \\
\hline \multicolumn{5}{|l|}{ Share of second largest operator } \\
\hline Number of licence holders & 16 & 3 & 7 & 1 \\
\hline Share of largest operator & 66 & 80 & 49 & 100 \\
\hline Share of second largest operator & 24 & & 16 & 0 \\
\hline \multicolumn{5}{|l|}{ Mobile cellular telephony: analogue } \\
\hline Number of licence holders & 1 & 1 & 2 & 1 \\
\hline Share of largest operator & 100 & 100 & & 100 \\
\hline Share of second largest operator & 0 & 0 & & 0 \\
\hline \multicolumn{5}{|l|}{ Mobile cellular telephony: digital } \\
\hline Number of licence holders & 2 & 6 & 4 & 2 \\
\hline Share of largest operator & 69 & 64 & 34 & 75 \\
\hline Share of second largest operator & 31 & 30 & & 25 \\
\hline
\end{tabular}


TABLE 1 Continued

\begin{tabular}{|c|c|c|c|c|}
\hline & Finland & Netherlands & United Kingdom & Turkey \\
\hline \multicolumn{5}{|l|}{ Ownership and Privatisation } \\
\hline Government ownership & 78.8 & 43.8 & 0 & 100 \\
\hline Year of privatisation & 1998 & 1994 & 1984 & - \\
\hline \multicolumn{5}{|l|}{ Price Regulation } \\
\hline \multicolumn{5}{|l|}{ Basic voice } \\
\hline Retail prices & No regulation & Objective benchmark & Objective benchmark & Discretionary \\
\hline Interconnection or access charges & Cost of the operator & $\begin{array}{l}\text { Trunk: Cost of the operator } \\
\text { Int.: no regulation }\end{array}$ & Objective benchmark & Cost of the operator \\
\hline \multicolumn{5}{|l|}{ Mobile } \\
\hline Retail prices & No regulation & No regulation & & Objective benchmark \\
\hline Interconnection or access charges & No regulation & & Cost of the operator & \\
\hline $\begin{array}{l}\text { Mandatory requirement to publish } \\
\text { the charges }\end{array}$ & Yes & Yes & Yes & No \\
\hline \multicolumn{5}{|l|}{ Independence of Regulatory Institutions } \\
\hline \multirow[t]{3}{*}{ Regulatory institutions } & Independent Telecom. Regulator & Independent Telecom. Regulator & Independent Telecom. Regulator & Competition Authority \\
\hline & Competition Authority & Competition Authority & Competition Authority & Ministry \\
\hline & Ministry & Ministry & Ministry & Other \\
\hline \multicolumn{5}{|l|}{$\begin{array}{l}\text { Division of regulatory responsibilities } \\
\text { for licensing }\end{array}$} \\
\hline Issuing licence & Ministry & $\begin{array}{l}\text { Independent Telecom. Regulator } \\
\text { Ministry in the case of mobile }\end{array}$ & Ministry & Ministry \\
\hline Oversight of licence requirements & Ministry & Independent Telecom. Regulator & $\begin{array}{l}\text { Independent Telecom. Regulator } \\
\text { + Ministry }\end{array}$ & Ministry \\
\hline Approval of merger & Competition Authority & Competition Authority & $\begin{array}{l}\text { Independent Telecom. Regulator } \\
+ \text { Competition Authority }\end{array}$ & \\
\hline \multicolumn{5}{|l|}{ Regulations on interconnection } \\
\hline $\begin{array}{l}\text { Authorisation of interconnection } \\
\text { charges }\end{array}$ & Independent Telecom. Regulator & Independent Telecom. Regulator & Independent Telecom. Regulator & No authorisation \\
\hline Dispute resolution & Independent Telecom. Regulator & Independent Telecom. Regulator & Independent Telecom. Regulator & Ministry \\
\hline Regulations on pricing & Competition Authority & Independent Telecom. Regulator & Independent Telecom. Regulator & Ministry \\
\hline Regulations on service quality & Independent Telecom. Regulator & Independent Telecom. Regulator & Independent Telecom. Regulator & No monitoring \\
\hline
\end{tabular}

In Turkey government ownership refers to ownership in telecommunications sector except mobile.

Source: Boylaud and Nicoletti (2000) for Finland, Netherlands and United Kingdom, and own estimations for Turkey. 
countries. While Finland does not regulate the retail prices, the Netherlands and Britain use objective benchmarking in the case of voice telephony. On the other hand, Finland regulates interconnection charges by cost-based mechanisms. While the Netherlands regulates interconnection charges in the case of trunk services, it does not regulate international calls, and Britain uses objective benchmarking in the case of basic voice services and cost-based mechanisms in the case of mobile services. Finally, we note that in the three EU countries the regulators are independent from the legislative and executive bodies, acquiring a semi-judiciary role. Another interesting feature is that basic competencies are shared among a ministry department, the sectoral regulator and the competition authority. While the first two are in general jointly responsible for entry, prices, dispute resolution and consumer policy, the competition authority has exclusive competencies for merger activity and applying competition rules. On the other hand, Turkey by 1998 did not have an independent telecommunications regulator and all authority was vested in the ministry department. The regulatory authority in Turkey was established, as emphasised above, by the beginning of 2000 .

Boylaud and Nicoletti (2000), using data similar to those reported in Table 1 for the 23 OECD economies over the period 1991-97, assess the effect of individual regulations and selected non-regulatory variables on measures of performance, for which they consider price, labour productivity and service quality. The authors note that the telecommunications sector is a heterogeneous service industry, and that its services include fixed-voice services (e.g. local, domestic and international long-distance telephony, and enhanced voice services), mobile services (mobile access, calls and messaging services), Internet services (e.g. dial-up and web hosting), data services (e.g. leased lines, asynchronous transfer mode (ATM) services, public data network services), and content services (e.g. pay-TV, online information and entertainment). They aggregate these services into five sectors: local, trunk (domestic long distance), international, mobile (cellular) telephony, and all other services including leased-line, pay-TV, Internet and data services. In their study they focus only on trunk, international, mobile and leased-line services and abstract from consideration in particular of local fixed-voice telephony services, as the latter, they emphasise, is largely monopolistic in a vast majority of OECD countries. Using econometric techniques they then estimate the effect of different regulations and selected non-regulatory variables on telecommunications prices. ${ }^{7}$ They obtain an average 'price' for each sector by dividing the total

\footnotetext{
${ }^{7}$ Boylaud and Nicoletti (2000) note that telecommunications prices are often two-part, consisting of a fixed charge that does not vary with use and a variable component that does. The variable component will often vary with, among other things, the type of service used, the length of use, the distance, and the time of day and week. Given these considerations, the authors note that some form of average price across the range of services provided in each sector is needed in order to undertake empirical work.
} 


\section{ERKAN AKDEMIR, ERDEM BAŞÇI AND SÜBIDEY TOGAN}

revenue collected in that sector by some measure of output by the sector (e.g. international call minutes). But for the trunk and leasing sectors, revenue estimates were not publicly available. Instead they used tariff baskets published by the OECD to measure prices in those sectors, where the tariff baskets represent a weighted average of listed prices faced by consumers in each economy for different products and services in each sector used at different times of the day and week.

In their econometric models, Boylaud and Nicoletti (2000) include five variables characterising the 'regulatory' environments that existed in the telecommunications industry in OECD economies: the market share of new entrants, an index of government control of the PTO, the degree of internationalisation of domestic markets, the time to liberalisation, and the time to privatisation. They include the 'market share of new entrants' variable as an indicator of market structure and the extent of actual competition, and as a crude proxy for the ease of entry, which is an outcome of liberalisation in telecommunication services. The 'index of government control' variable indicates the extent of public ownership of the PTO. The authors use the 'degree of internationalisation of domestic markets' variable - the number of foreign telecommunications operators participating in joint ventures or other cooperation agreements with domestic operators in the domestic market - to approximate the entry restrictions faced by foreign firms and the extent of foreign investment. Noting that the announcement of new entry, or a change in the ownership structure of the PTO, may influence the level and mix of inputs, outputs and prices well in advance of the actual changes coming into effect, the authors included a 'time to liberalisation' variable and a 'time to privatisation' variable, which respectively measured the number of years to liberalisation and privatisation. In addition to regulatory variables the authors include three non-regulatory environmental variables in their models - a measure of capital intensity, a measure of input costs and a price rebalancing indicator. The 'technology' variable used by the authors - total fixed telecommunications investment per mainline - is a proxy for capital intensity in the industry. Similarly, the 'economic structure' variable - total operating expenditure per mainline - was included as a measure of input costs on the grounds that prices will generally reflect the cost of inputs, such as labour, maintenance and other (non-capital) operating costs in the industry. Finally, the 'price rebalancing indicator', measured by the distance of price structure from that in the UK in 1998, was included to account for deviations between underlying costs and prices for individual telecommunications services.

Boylaud and Nicoletti (2000), investigating the linkages between regulatory regimes, market environments and performance in domestic long distance, international long distance, mobile telecommunications and leased-line services, conclude that liberalisation of entry and the development of effective competition in telecommunications services lead to lower prices, higher productivity and better 
quality. An alternative, but in principle a similar approach was adopted by Warren (2000a), who considers four types of impediments to trade in telecommunications services: restrictions on cross-border trade, restrictions on establishment, restrictions on direct investment in fixed and mobile network services, and restrictions on ongoing operations. In each case Warren derives index values, where higher values indicate greater restrictions. While the index of restrictions to cross-border trade captures policies that discriminate against all potential entrants (domestic and foreign) seeking to supply cross-border telecommunications services, the index of restrictions on establishment captures policies that discriminate against all potential entrants (domestic and foreign) seeking to supply the telecommunications services via investment in the country. ${ }^{8}$ The index of restrictions on direct investment is designed to capture policies that discriminate against potential foreign entrants seeking to supply telecommunications services via investment in the country. Finally, the index of restrictions on ongoing operations captures policies that discriminate against potential foreign entrants seeking to supply cross-border telecommunications services. Given the index values derived from an international survey undertaken by the International Telecommunications Union (1998) for 136 countries, Warren (2000b) estimates first the impact of impediments to trade and investment in telecommunications services on the penetration of fixed and mobile telecommunications network and thereafter the price impact. The results are shown in Table 2.

The table reveals that Finland and the United Kingdom follow liberal trade and investment policies in the telecommunications sector. Assuming that Turkey with liberalisation of telecommunications services will implement similar rules and regulations as those followed by Finland and the UK, we note from Table 2 that with liberalisation Turkish telecommunications prices will be reduced by 33.53 per cent relative to the base case prices.

\section{b. Restrictions on the Telecommunications Services during 2005}

To estimate the ad valorem equivalent of barriers to the telecommunications services sector in Turkey prevailing during 2005 we calculate the restrictiveness index following an approach similar to that of McGuire and Schuele (2000) and Kimura et al. (2003). Tables 3-5 show for fixed-line, mobile services and Internet services respectively, the restriction categories, weights for them, and scoring for each category. The weights show the importance of the category in terms of how significantly the restriction of the category would limit service suppliers from

\footnotetext{
${ }^{8}$ The index of restrictions on establishment is derived from scores to the questions: (i) Does competition operate in the market? (ii) Does policy allow for competition in the market? (iii) Is the incumbent privatised?
} 
TABLE 2

Restrictiveness Index Scores for Telecommunications Services

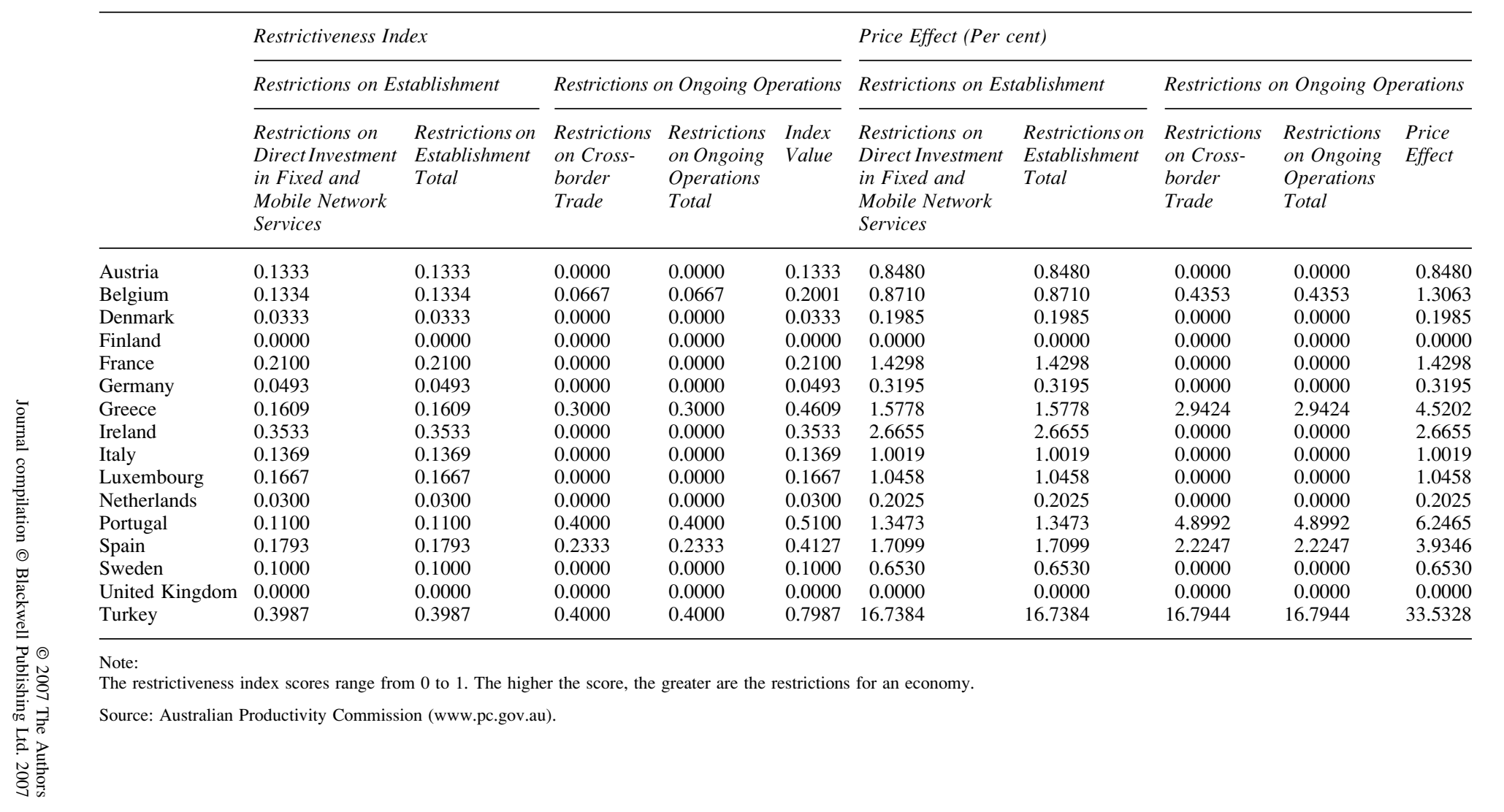


TABLE 3

The Foreign Restrictiveness Index: Restrictions on the Fixed-line Sector in Turkey, 2005

Weight Scoring $\begin{aligned} & \text { Score Category } \\ & \text { Chosen }\end{aligned}$

0.20

$\begin{array}{ll}1.00 & 1.00 \\ 0.75 & \\ 0.20 & \\ 0.10 & \\ 0.00 & \\ & \\ 1.00 & \\ 0.75 & \\ 0.20 & 0.20 \\ & \\ 0.10 & \\ 0.00 & \\ & \\ 1.00 & \\ 0.75 & \\ 0.20 & 0.20 \\ 0.10 & \\ 0.00 & \end{array}$

0.10

$1.00 \quad 1.00$

$0.00 \quad 0.00$

0.20

0.10

$$
1.00
$$

0.00

\section{Restrictions on Commercial Presence}

Licensing of fixed-line services

(a) Regional line service No new licence allowed Licences are issued through complicated (discriminately) and costly procedures Licences are generally issued with application fee and several requirements

Licences are generally issued with application fee Licences are automatically issued upon application without any cost

(b) Domestic long-distance line service

No new licence allowed

Licences are issued through complicated (discriminately) and costly procedures

Licences are generally issued with application fee and several requirements

Licences are generally issued with application fee

Licences are automatically issued upon application without any cost

(c) International line service

No new licence allowed

Licences are issued through complicated (discriminately)

and costly procedures

Licences are generally issued with application fee and several requirements

Licences are generally issued with application fee

Licences are automatically issued upon application without any cost

Form of commercial presence

(a) Regional line service

Measures which restrict or require a specific type of establishment

No restriction on establishment

(b) Domestic long-distance line service

Measures which restrict or require a specific type of establishment

No restriction on establishment

(c) International line service

Measures which restrict or require a specific type of establishment

No restriction on establishment

Direct investment: equity participation permitted

The score is inversely proportional to the maximum equity participation permitted in an existing domestic company

Direct investment: restrictions on certain types of services

Restrictions on providing some types of telephone services

No restrictions on providing any type of telephone services

Joint-venture arrangements

Issues no new licence and no entry is allowed through a joint venture with a domestic company 


\section{ERKAN AKDEMIR, ERDEM BAŞÇI AND SÜBIDEY TOGAN}

TABLE 3 Continued

\begin{tabular}{|c|c|c|c|}
\hline Weight & Scoring & $\begin{array}{l}\text { Score } \\
\text { Chosen }\end{array}$ & Category \\
\hline \multirow{9}{*}{0.02} & 0.50 & & $\begin{array}{l}\text { Foreign company can enter only through a joint venture with a } \\
\text { domestic company }\end{array}$ \\
\hline & 0.00 & 0.00 & $\begin{array}{l}\text { No requirement for foreign companies to enter through a joint } \\
\text { venture with a domestic company }\end{array}$ \\
\hline & & & Permanent movement of people \\
\hline & 1.00 & & No entry of executives, senior managers and/or specialists \\
\hline & 0.80 & & Executives, specialists and/or senior managers can stay up to 1 year \\
\hline & 0.60 & & Executives, specialists and/or senior managers can stay up to 2 years \\
\hline & 0.40 & & Executives, specialists and/or senior managers can stay up to 3 years \\
\hline & 0.20 & & Executives, specialists and/or senior managers can stay up to 4 years \\
\hline & 0.00 & 0.00 & $\begin{array}{l}\text { Executives, specialists and/or senior managers can stay a period of } \\
5 \text { years or more }\end{array}$ \\
\hline \multirow{4}{*}{0.10} & & & Other Restrictions \\
\hline & & & Third-party resale of lease line \\
\hline & 1.00 & & Resale is not permitted \\
\hline & 0.00 & 0.00 & Resale is permitted in any market \\
\hline \multirow[t]{4}{*}{0.05} & & & End-user tariff \\
\hline & 1.00 & & End-user tariff is determined by rate of return regulation \\
\hline & 0.50 & 0.50 & End-user tariff is determined by price cap established by the authority \\
\hline & 0.00 & & End-user tariff is determined by market force (no regulation) \\
\hline \multirow[t]{4}{*}{0.05} & & & Regulation of network interconnection \\
\hline & 1.00 & & Interconnection is completely regulated by the authority \\
\hline & 0.50 & 0.50 & $\begin{array}{l}\text { Interconnection is determined by private negotiations in general, } \\
\text { but general terms are determined by the authority }\end{array}$ \\
\hline & 0.00 & & $\begin{array}{l}\text { Interconnection is completely determined by private negotiations } \\
\text { (no regulation) }\end{array}$ \\
\hline \multirow[t]{10}{*}{0.05} & & & Market structure \\
\hline & & & (a) Regional line service \\
\hline & 1.00 & 1.00 & Monopoly \\
\hline & 0.00 & & Competition among plural providers \\
\hline & & & (b) Domestic long-distance line service \\
\hline & 1.00 & & Monopoly \\
\hline & 0.00 & 0.00 & Competition among plural providers \\
\hline & & & (c) International line service \\
\hline & 1.00 & & Monopoly \\
\hline & 0.00 & 0.00 & Competition among plural providers \\
\hline \multirow[t]{2}{*}{0.02} & & & Composition of board of directors \\
\hline & & 0.00 & $\begin{array}{l}\text { The score is inversely proportional to the percentage of the board } \\
\text { that can comprise foreigners }\end{array}$ \\
\hline \multirow[t]{6}{*}{0.01} & & & Temporary movement of people \\
\hline & 1.00 & & $\begin{array}{l}\text { No temporary entry of executives, senior managers and/or } \\
\text { specialists }\end{array}$ \\
\hline & 0.75 & & $\begin{array}{l}\text { Temporary entry of executives, specialists and/or senior managers } \\
\text { up to } 30 \text { days }\end{array}$ \\
\hline & 0.50 & & $\begin{array}{l}\text { Temporary entry of executives, specialists and/or senior managers } \\
\text { up to } 60 \text { days }\end{array}$ \\
\hline & 0.25 & & $\begin{array}{l}\text { Temporary entry of executives, specialists and/or senior managers } \\
\text { up to } 90 \text { days }\end{array}$ \\
\hline & 0.00 & 0.00 & $\begin{array}{l}\text { Temporary entry of executives, specialists and/or senior managers } \\
\text { over } 90 \text { days }\end{array}$ \\
\hline
\end{tabular}

Source: Kimura et al. (2003). 
TABLE 4

The Foreign Restrictiveness Index: Restrictions on the Mobile Services in Turkey, 2005

Weight Scoring $\begin{aligned} & \text { Score Category } \\ & \text { Chosen }\end{aligned}$

0.20

1.00

0.75

$0.20 \quad 0.20$

0.10

0.00

0.10

1.00

$0.00 \quad 0.00$

0.20

0.10

1.00

0.00

0.00

0.10

0.50

$0.00 \quad 0.00$

0.02

1.00

0.80

0.60

0.40

0.20

0.00

0.00

0.05

1.00

$0.50 \quad 0.50$

0.00

0.10

1.00

0.50

$0.00 \quad 0.00$

0.05

1.00

0.20

\section{Restrictions on Commercial Presence}

Licensing of mobile phone services

No new licence allowed

Licences are issued through complicated (discriminately) and costly procedures

Licences are generally issued with application fee and several requirements

Licences are generally issued with application fee

Licences are automatically issued upon application without any cost

Form of commercial presence

Measures which restrict or require a specific type of establishment

No restriction on establishment

Direct investment: equity participation permitted

The score is inversely proportional to the maximum equity participation permitted in an existing domestic company

Direct investment: restrictions on certain types of services

Restrictions on providing some types of telephone services

No restrictions on providing any type of telephone services

Joint-venture arrangements

Issues no new licence and no entry is allowed through a joint

venture with a domestic company

Foreign company can enter only through a joint venture with a

domestic company

No requirement for foreign companies to enter through a joint venture with a domestic company

Permanent movement of people

No entry of executives, senior managers and/or specialists

Executives, specialists and/or senior managers can stay up to 1 year

Executives, specialists and/or senior managers can stay up to 2 years

Executives, specialists and/or senior managers can stay up to 3 years

Executives, specialists and/or senior managers can stay up to 4 years

Executives, specialists and/or senior managers can stay a period of 5 years or more

\section{Other Restrictions}

Regulation of interconnection between fixed line and mobile or between mobiles

Interconnection is completely regulated by the authority

Interconnection is determined by private negotiations in general, but general terms are determined by the authority

Interconnection is completely determined by private negotiations (no regulation)

End-user tariff

End-user tariff is determined by rate of return regulation

End-user tariff is determined by price cap established by the authority

End-user tariff is determined by market force (no regulation)

Allocation of radio spectrum

Allocation is discriminately decided by the authority

Allocated by auction with application fee 


\section{ERKAN AKDEMIR, ERDEM BAŞÇI AND SÜBIDEY TOGAN}

TABLE 4 Continued

\begin{tabular}{|c|c|c|c|}
\hline Weight & Scoring & $\begin{array}{l}\text { Score } \\
\text { Chosen }\end{array}$ & Category \\
\hline & 0.10 & & Allocated by auction without application fee \\
\hline & 0.00 & 0.00 & Radio frequencies are obtained with mobile services \\
\hline \multirow[t]{3}{*}{0.05} & & & Market structure \\
\hline & 1.00 & & Monopoly \\
\hline & 0.00 & 0.00 & Competition among plural providers \\
\hline \multirow[t]{2}{*}{0.02} & & & Composition of board of directors \\
\hline & & 0.00 & $\begin{array}{l}\text { The score is inversely proportional to the percentage of the board } \\
\text { that can comprise foreigners }\end{array}$ \\
\hline \multirow[t]{6}{*}{0.01} & & & Temporary movement of people \\
\hline & 1.00 & & No temporary entry of executives, senior managers and/or specialists \\
\hline & 0.75 & & $\begin{array}{l}\text { Temporary entry of executives, specialists and/or senior managers } \\
\text { up to } 30 \text { days }\end{array}$ \\
\hline & 0.50 & & $\begin{array}{l}\text { Temporary entry of executives, specialists and/or senior managers } \\
\text { up to } 60 \text { days }\end{array}$ \\
\hline & 0.25 & & $\begin{array}{l}\text { Temporary entry of executives, specialists and/or senior managers } \\
\text { up to } 90 \text { days }\end{array}$ \\
\hline & 0.00 & 0.00 & $\begin{array}{l}\text { Temporary entry of executives, specialists and/or senior managers } \\
\text { over } 90 \text { days }\end{array}$ \\
\hline
\end{tabular}

Source: Kimura et al. (2003).

TABLE 5

The Foreign Restrictiveness Index: Restrictions on Internet Services in Turkey, 2005

Weight Scoring $\begin{aligned} & \text { Score Category } \\ & \text { Chosen }\end{aligned}$

0.20

1.00

0.75

0.20

$0.10 \quad 0.10$

0.00

0.10

1.00

$0.00 \quad 0.00$

0.20

0.00

0.10

1.00

$0.00 \quad 0.00$

0.10

1.00

\section{Restrictions on Commercial Presence}

Licensing of Internet services

No new licence allowed

Licences are issued through complicated (discriminately) and costly procedures

Licences are generally issued with application fee and several requirements

Licences are generally issued with application fee

Licences are automatically issued upon application without any cost

Form of commercial presence

Measures which restrict or require a specific type of establishment No restriction on establishment

Direct investment: equity participation permitted

The score is inversely proportional to the maximum equity participation permitted in an existing domestic company

Direct investment: restrictions on certain types of services Restrictions on providing some types of Internet services No restrictions on providing any type of Internet services

Joint-venture arrangements

Issues no new licence and no entry is allowed through a joint venture with a domestic company 
TABLE 5 Continued

\begin{tabular}{|c|c|c|c|}
\hline Weight & Scoring & $\begin{array}{l}\text { Score } \\
\text { Chosen }\end{array}$ & Category \\
\hline & 0.50 & & $\begin{array}{l}\text { Foreign company can enter only through a joint venture with a } \\
\text { domestic company }\end{array}$ \\
\hline & 0.00 & 0.00 & $\begin{array}{l}\text { No requirement for foreign companies to enter through a joint } \\
\text { venture with a domestic company }\end{array}$ \\
\hline \multirow[t]{8}{*}{0.02} & & & Permanent movement of people \\
\hline & 1.00 & & No entry of executives, senior managers and/or specialists \\
\hline & 0.80 & & Executives, specialists and/or senior managers can stay up to 1 year \\
\hline & 0.60 & & Executives, specialists and/or senior managers can stay up to 2 years \\
\hline & 0.40 & & Executives, specialists and/or senior managers can stay up to 3 years \\
\hline & 0.20 & & Executives, specialists and/or senior managers can stay up to 4 years \\
\hline & 0.00 & 0.00 & $\begin{array}{l}\text { Executives, specialists and/or senior managers can stay a period of } \\
5 \text { years or more }\end{array}$ \\
\hline & & & Other Restrictions \\
\hline \multirow[t]{4}{*}{0.10} & & & $\begin{array}{l}\text { Regulation of interconnection agreements among Internet service } \\
\text { providers }\end{array}$ \\
\hline & 1.00 & & Interconnection is completely regulated by the authority \\
\hline & 0.50 & & $\begin{array}{l}\text { Interconnection is determined by private negotiations in general, } \\
\text { but general terms are determined by the authority }\end{array}$ \\
\hline & 0.00 & 0.00 & $\begin{array}{l}\text { Interconnection is completely determined by private negotiations } \\
\text { (no regulation) }\end{array}$ \\
\hline \multirow[t]{4}{*}{0.10} & & & Infrastructure \\
\hline & 1.00 & 1.00 & $\begin{array}{l}\text { Providers are not allowed to either build their own network or } \\
\text { own/lease their international data gateways }\end{array}$ \\
\hline & 0.50 & & $\begin{array}{l}\text { Providers are allowed to build their own network or own/lease } \\
\text { their international data gateways }\end{array}$ \\
\hline & 0.00 & & $\begin{array}{l}\text { Providers are allowed to build their own network as well as own/ } \\
\text { lease their international data gateways }\end{array}$ \\
\hline \multirow[t]{3}{*}{0.05} & & & Market structure \\
\hline & 1.00 & & Monopoly \\
\hline & 0.00 & 0.00 & Competition among plural providers \\
\hline \multirow[t]{2}{*}{0.02} & & & Composition of board of directors \\
\hline & & 0.00 & $\begin{array}{l}\text { The score is inversely proportional to the percentage of the board } \\
\text { that can comprise foreigners }\end{array}$ \\
\hline \multirow[t]{6}{*}{0.01} & & & Temporary movement of people \\
\hline & 1.00 & & $\begin{array}{l}\text { No temporary entry of executives, senior managers and/or } \\
\text { specialists }\end{array}$ \\
\hline & 0.75 & & $\begin{array}{l}\text { Temporary entry of executives, specialists and/or senior managers } \\
\text { up to } 30 \text { days }\end{array}$ \\
\hline & 0.50 & & $\begin{array}{l}\text { Temporary entry of executives, specialists and/or senior managers } \\
\text { up to } 60 \text { days }\end{array}$ \\
\hline & 0.25 & & $\begin{array}{l}\text { Temporary entry of executives, specialists and/or senior managers } \\
\text { up to } 90 \text { days }\end{array}$ \\
\hline & 0.00 & 0.00 & $\begin{array}{l}\text { Temporary entry of executives, specialists and/or senior managers } \\
\text { over } 90 \text { days }\end{array}$ \\
\hline
\end{tabular}

Source: Kimura et al. (2003). 
entering or operating in the market. The sum of weights for all categories is 1 . A score with a range from 0 (least restrictive) to 1 (most restrictive) is assigned for each category, according to the degree of restrictiveness, so that the score reflects the type of restriction imposed by the economy.

In Tables 3-5 the restriction categories are classified into 'restrictions on commercial presence' and 'other restrictions'. In the case of fixed-line, mobile and Internet services the 'restrictions on commercial presence' include 'licensing of fixed-line services', 'form of commercial presence', 'direct investment: equity participation permitted', 'direct investment: restrictions on certain types of services', 'joint-venture arrangements' and 'permanent movement of people'. On the other hand, 'other restrictions' in the case of fixed-line services include 'thirdparty resale of lease line', 'end-user tariff', 'regulation of network interconnection', 'market structure', 'composition of board of directors' and 'temporary movement of people'. In the case of mobile services 'other restrictions' include 'allocation of radio spectrum' instead of 'third-party resale of lease line' of fixed-line services, and in the case of Internet services 'other restrictions' include 'infrastructure' instead of 'third-party resale' and 'end-user tariff' of fixed-line services. Among restrictions 'licensing of fixed-line services' and 'direct investment: equity participation permitted' have a weight of 20 per cent each. These weights indicate that those barriers are the most important ones.

The tables reveal that in Turkey as of 2005 there are no restrictions on direct investments and on permanent movement of people. Comparing the restrictions in fixed-line, mobile and Internet services we note that there are fewer restrictions in mobile and Internet services than in fixed-line services.

Table 6 shows the foreign restrictiveness index (FR) values for Turkish fixedline, mobile and Internet services. The FR value equals 0.193 in the case of fixedline, 0.165 in the case of mobile, and 0.12 in the case of Internet services. To convert these index values into tariff equivalents we use coefficients presented by Warren (2000b) that estimate quantity impact and tariff equivalents of restrictions on fixed-line and mobile service sectors. The regression results obtained by Warren (2000b) for fixed-line services and mobile services are presented in Table 7. In the table the penetration rate of fixed network (mainlines per 100 inhabitants denoted by $q_{f}$ ) is regressed on GDP per capita $(y)$, household density (number of households per square $\mathrm{km}$ denoted by $h d$ ), per cent of mainlines connected to digital exchange (dshare), waiting list as per cent of total demand for mainlines (wait), population density (number of persons per square km denoted by $p d$ ) and measure of trade policy $\left(p_{f}\right)$. On the other hand, the penetration rate of the mobile network (cellular phones per 100 inhabitants denoted by $q_{m}$ ) is regressed on $y$, $p d$ and measure of trade policy $\left(p_{m}\right)$.

Denoting the value of the trade policy variable under full liberalised policy approach by $p_{i}^{*}$, the associated value of the dependent variable by $q_{i}^{*}$ and the price elasticity of demand by $\eta_{i}(i=f, m)$ we note that: 
TABLE 6

The Estimated Restrictiveness Indexes

\begin{tabular}{ll}
\hline Weight & $\begin{array}{l}\text { Estimated Score } \\
\text { (FR index) }\end{array}$
\end{tabular}

\section{Fixed Line}

$\begin{array}{ll}0.20 & 0.093 \\ 0.10 & 0.033 \\ 0.20 & 0.000 \\ 0.10 & 0.000 \\ 0.10 & 0.000 \\ 0.02 & 0.000 \\ & \\ 0.10 & 0.000 \\ 0.05 & 0.025 \\ 0.05 & 0.025 \\ 0.05 & 0.017 \\ 0.02 & 0.000 \\ 0.01 & 0.000\end{array}$

Index Value 0.193

Mobile Services

$\begin{array}{ll}0.20 & 0.040 \\ 0.10 & 0.000 \\ 0.20 & 0.000 \\ 0.10 & 0.000 \\ 0.10 & 0.000 \\ 0.02 & 0.000 \\ & \\ 0.05 & 0.025 \\ & \\ 0.10 & 0.000 \\ 0.05 & 0.000 \\ 0.05 & 0.000 \\ 0.02 & 0.000 \\ 0.01 & 0.000 \\ \text { Index Value } & 0.065\end{array}$

Internet Services

$\begin{array}{ll}0.20 & 0.020 \\ 0.10 & 0.000 \\ 0.20 & 0.000 \\ 0.10 & 0.000 \\ 0.10 & 0.000 \\ 0.02 & 0.000 \\ & \\ 0.10 & 0.000 \\ & \\ 0.10 & 0.100 \\ 0.05 & 0.000 \\ 0.02 & 0.000 \\ 0.01 & 0.000 \\ \text { Index Value } & 0.120\end{array}$

\section{Restrictions on Commercial Presence}

Licensing of fixed-line services

Form of commercial presence

Direct investment: equity participation permitted

Direct investment: restrictions on certain types of services Joint-venture arrangements

Permanent movement of people

\section{Other Restrictions}

Third-party resale of lease line

End-user tariff

Regulation of network interconnection

Market structure

Composition of board of directors

Temporary movement of people

\section{Restrictions on Commercial Presence}

Licensing of mobile phone services

Form of commercial presence

Direct investment: equity participation permitted

Direct investment: restrictions on certain types of services Joint-venture arrangements

Permanent movement of people

Other Restrictions

Regulation of interconnection between fixed line and

mobile or between mobiles

End-user tariff

Allocation of radio spectrum

Market structure

Composition of board of directors

Temporary movement of people

\section{Restrictions on Commercial Presence}

Licensing of Internet services

Form of commercial presence

Direct investment: equity participation permitted

Direct investment: restrictions on certain types of services

Joint-venture arrangements

Permanent movement of people

\section{Other Restrictions}

Regulation of interconnection agreements among Internet service providers

Infrastructure

Market structure

Composition of board of directors

Temporary movement of people 
TABLE 7

The Estimate Results for the Fixed-line and Mobile Penetration Models

\begin{tabular}{|c|c|c|c|c|}
\hline & \multicolumn{2}{|c|}{ The Fixed Penetration Model } & \multicolumn{2}{|c|}{ The Mobile Penetration Model } \\
\hline & Coefficient & Standard Error & Coefficient & Standard Error \\
\hline Constant & 12.26 & 2.66 & -1.3 & 0.7 \\
\hline GDP per capita $(y)$ & 0.004 & 0.0003 & 0.0008 & 0.00005 \\
\hline$y^{2}+1-2$ & $-6.30 \mathrm{E}-08$ & 0.0 & $-1.90 \mathrm{E}-09$ & 0.0 \\
\hline$y^{3}$ & $1.30 \mathrm{E}-13$ & 0.0 & & \\
\hline Household density $(h d)$ & 0.003 & 0.003 & & \\
\hline Waiting list (wait) & -0.08 & 0.05 & & \\
\hline Digitised network share (dshare) & -0.13 & 0.03 & & \\
\hline Population density $(p d)$ & & & 0.001 & 0.0006 \\
\hline Policy variable (1-FR index) & 5.26 & 3.11 & & \\
\hline Adjusted $R$-squared & \multicolumn{2}{|c|}{0.89} & \multicolumn{2}{|c|}{0.78} \\
\hline
\end{tabular}

Notes:

Dependent variable for the fixed penetration model: mainlines per 100 inhabitants.

Dependent variable for the mobile penetration model: cellular mobile subscribers per 100 inhabitants.

Source: Warren (2000b, Model 5 in Table 6.5 and Model 7 in Table 6.6).

$$
\frac{q_{f}^{*}-q_{f}}{q_{f}}=\eta_{f}\left[\frac{p_{f}^{*}-p_{f}}{p_{f}}\right] \text { and } \frac{q_{m}^{*}-q_{m}}{q_{m}}=\eta_{m}\left[\frac{p_{m}^{*}-p_{m}}{p_{m}}\right],
$$

where subscripts $f$ and $m$ refer to fixed-line and mobile services respectively. Hence, the tariff equivalents $\left(\mathrm{TE}_{i}\right)$ are obtained as:

$$
\left[\frac{p_{f}^{*}-p_{f}}{p_{f}}\right] 100=\mathrm{TE}_{f} \text { and }\left[\frac{p_{m}^{*}-p_{m}}{p_{m}}\right] 100=\mathrm{TE}_{m} \cdot{ }^{9}
$$

Based on these equations we calculate ad valorem tariff equivalents of restrictions prevailing during 2005 in the fixed-line services as 2.7 per cent, in mobile services as 3.43 per cent and in Internet services as 1.64 per cent. ${ }^{10}$ The tariff equivalent of restrictions in the telecommunications sector obtained as weighted average of the tariff equivalents of restrictions in fixed-line, mobile and Internet

\footnotetext{
${ }^{9}$ When calculating the values of $q_{i}, q_{i}^{*}$ and $\operatorname{TE}_{i}(i=f, m)$ we use the following values for the variables: $y=\mathrm{US} \$ 4,210, h d=19.2$, wait $=2.62$ per cent, dshare $=0.9, \eta=-1.2$ and policy variable $p=(1-\mathrm{FR})$. The values of the parameters are obtained from the World Bank (2005), OECD (2005) and International Telecommunications Union. On the other hand, we get the FR values from Table 6, the FR values under full liberalisation from Table 2 for the UK and Finland, and the value of the price elasticity of demand $\eta$ from Albon et al. (1997).

${ }^{10}$ On the calculation of tariff equivalents see Kimura (2003) and Dee (2003).
} 
services weighted by sectoral employment levels is then 2.74 per cent. The calculations reveal that the Turkish telecommunications sector as of 2005 is quite liberal, but that further efforts are needed for complete liberalisation of the sector.

\section{c. Implications of EU Accession}

To study the economic effects of EU integration in the telecommunications sector we compare the situation of the Turkish economy in the base case with the case when Turkey adopts and implements in the telecommunications sector all of the rules and regulations of the EU. As the 'base case' we consider the Turkish economy with rules and regulations as they have prevailed during the latter half of the 1990s, when Turkey did not introduce the EU rules and regulations in the telecommunications sector. Here we base our analysis of the linkages between regulatory regimes and performance indicators of Table 2. From the table we learn that Finland and the UK follow liberal trade and investment policies in the telecommunications sector. We then assume that Turkey with liberalisation implements similar rules and regulations as those followed by Finland and the UK. Table 2 then reveals that with liberalisation Turkish telecommunications prices will be reduced by 33.53 per cent relative to the base case prices.

Given the change in the price of telecommunications resulting from the change in the Turkish regulatory regime one can compute the change in Turkish consumer surplus as a measure of the welfare effect of EU integration from information on the consumer demand schedule for telecommunications. But telecommunications is an intermediate good for business users that is used in the production of other commodities. Hence, prices of other commodities in the economy will change as a result of the change in the price of telecommunications. To study the welfare effects of EU integration one has to consider not only the change in consumer surplus due to the change in the price of telecommunications but also the changes in consumer surpluses due to the changes in the prices of other commodities.

To analyse the effect of the change in the price of telecommunications on the prices of other commodities we consider the 1996 input-output table of the Turkish economy which has 97 sectors. Telecommunications is sector 83 . Let $A$ be the $97 \times 97$ matrix of input coefficients. Given $A$, form the $96 \times 96$ input matrix $B$ by deleting the 83 rd column and 83 rd row referring to the telecommunications sector. Denote the 83rd row where the 83rd column element has been deleted by $e$. Let $p$ be the $1 \times 96$ price vector of the 96 commodities excluding the telecommunications sector and $v a$ the corresponding $1 \times 96$ unit gross valueadded vector. The price equation can be written as:

$$
p=p B+p_{t} e+v a,
$$




\section{ERKAN AKDEMIR, ERDEM BAŞÇI AND SÜBIDEY TOGAN}

where $p_{t}$ denotes the price of the telecommunications services. Hence we have:

$$
p=p_{t} e(I-B)^{-1}+v a(I-B)^{-1} .
$$

Thus, given the price of telecommunications that will prevail in Turkey after it adopts and implements the EU rules and regulations, $p_{t}$, we determine the equilibrium prices of the other 96 commodities from the above equation assuming that there is no change in the unit gross value-added vector $v a$. Given the equilibrium price vector $p$ form the $1 \times 97$ price vector as $\pi=\left(p p_{t}\right)$. Let $C O N$ be the $96 \times 1$ consumption expenditure vector obtained from the 1996 inputoutput table by deleting the value of consumption of the telecommunications sector and $\mathrm{con}_{t}$ the value of consumption of telecommunications services. Form the $97 \times 1$ consumption vector as:

$$
\text { CONS }=\left[\begin{array}{c}
C O N \\
\operatorname{con}_{t}
\end{array}\right]
$$

Noting that initially all base year prices equal unity we can express the value of total consumption expenditure evaluated at base prices as:

$$
C=u C O N S,
$$

where $u$ denotes the $1 \times 97$ unit vector. The value of total consumption expenditure evaluated at the prices that will prevail after Turkey adopts and implements the EU rules and regulations in the telecommunications sector is then given by:

$$
C^{*}=\pi \text { CONS }
$$

The effect on consumer welfare can now be calculated as:

$$
\left(C-C^{*}\right) \times 100 / C^{*} \cdot 11
$$

Note that this measure of the change in consumer welfare gives a downwardbiased estimate of the welfare effect as we do not consider the increases in consumer demands for the different commodities with the decreases in the prices of these commodities. But such an estimate would require the use of price elasticities of demand for the 97 commodities of the input-output table, which we did not have at our disposal. Thus, the welfare gain will have to be higher than the figure given by the estimate we present in this paper.

\footnotetext{
${ }^{11}$ Note that this approach determines the equivalent variation in consumer income.
} 
By construction, prices in 1996, the year the input-output table has been constructed for, are all unity in the input-output table. We assume that with the adoption of the EU rules and regulations in the telecommunications sector, the telecommunications price will decrease by 33.53 per cent, as indicated in Section $3 a$. Hence, with the new price of telecommunications we observe that the welfare of society will increase by 0.587 per cent. Thus, the effect of the adoption of EU rules and regulations in the telecommunications sector similar to those of Finland and the UK amounts to a US\$1.12 billion annual increase in the real income of the Turkish consumers. Since, during 1996, consumption formed 72.95 per cent of GDP, the percentage change in welfare of the society is equivalent to a 0.428 per cent increase in real GDP. Finally, we note that as of 2005 Turkey has adopted most of the EU rules and regulations in the telecommunications sector. With further alignment of these rules and regulations to those of the EU and strict implementation of these rules and regulations by TA, Turkey could derive the welfare gains calculated above.

Since the estimates of the price wedges due to service barriers are the key parameters determining the welfare effects of services liberalisation in the above calculations, we compare our estimates of tariff equivalents with estimates from other sources. Figures 1 and 2 show respectively the telecommunications prices for business and residential customers in selected countries. The figures reveal that the price wedge implicit in these figures are much larger than the figure of

FIGURE 1

OECD Composite Basket of Business Telephone Charges, August 2004

(Excluding VAT)

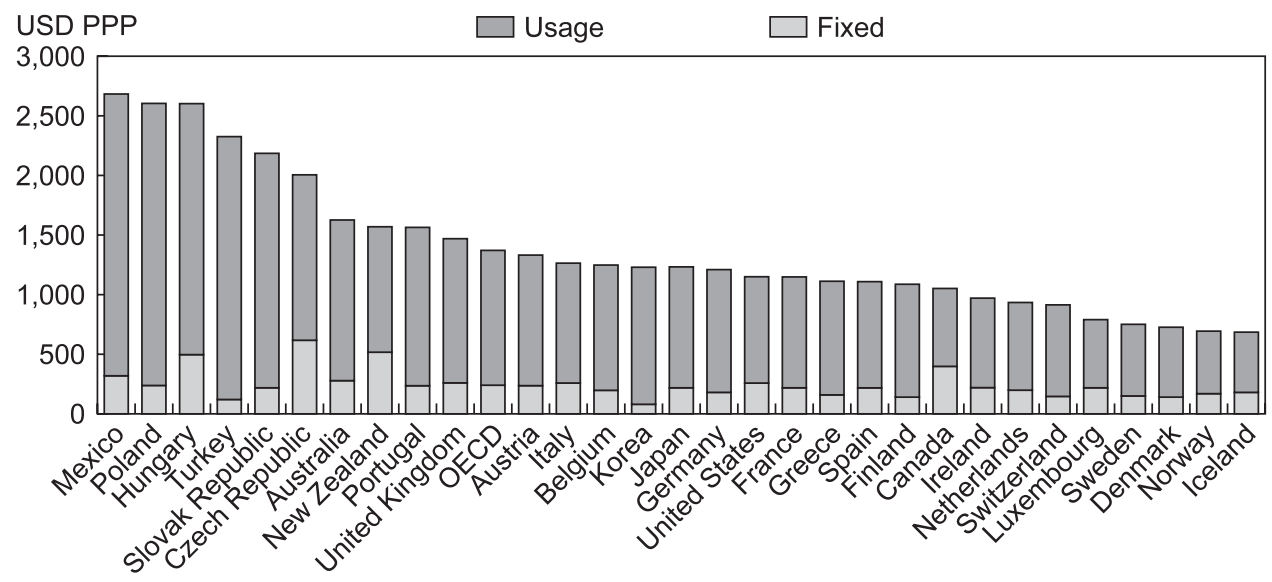

Source: OECD (2005). 


\section{ERKAN AKDEMIR, ERDEM BAŞÇI AND SÜBIDEY TOGAN}

FIGURE 2

OECD Composite Basket of Residential Telephone Charges, August 2004

(Including VAT)

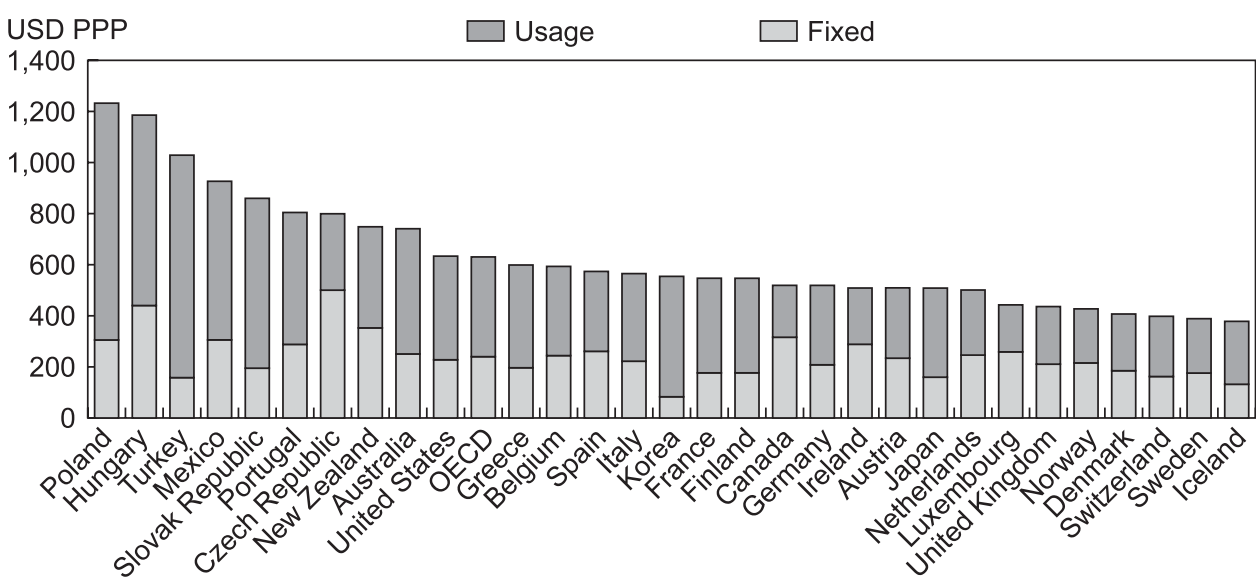

Source: OECD (2005).

33.5 per cent we have used in our calculations. ${ }^{12}$ Thus, our estimates of price wedge in the telecommunications sector is rather conservative and our estimate of the effects of liberalisation in telecommunications services gives the lower bound of the welfare gains derived in the sector.

On the other hand, we note that there are very few studies on the measurement of barriers to the telecommunications services sector in Turkey. One such study has been conducted by Hoekman (1996) who uses information contained in the country schedules of the General Agreement on Trade in Services (GATS). Hoekman's estimates for Turkey are 92.9 per cent in the basic telecommunications sector and 42.9 per cent and in the value-added telecommunications sector. ${ }^{13}$ But these estimates have, as emphasised by Stern (2002), certain drawbacks. First, the method assumes that the absence of positive country commitments in the GATS schedules can be interpreted as indicating the presence of restrictions.

12 The implicit price wedge is derived from the relation $p=p^{*}(1+t)$, where $p$ refers to the Turkish price, $p^{*}$ the best-practice price in the $\mathrm{EU}$, and $t$ is the price wedge parameter.

${ }^{13}$ Hoekman (1996) constructs frequency ratios on the basis of commitments scheduled in the GATS. He considers the four modes of supply of the GATS: (i) cross-border supply where a service is supplied from a supplier's country of residence to a consumer's country of residence, (ii) consumption abroad where a service is supplied through the movement of a consumer to a supplier's country of residence, (iii) commercial presence where a service is supplied through the movement of a commercial organisation to a consumer's country of residence, and (iv) presence of a natural person where a service is supplied through the movement of a natural person to a consumer's country of residence. He classifies the GATS commitments into three categories, 
Second, the different types of restrictions are given equal weight and are not distinguished according to their economic impact. Finally, the method assumes that market access restrictions are the only type of barriers to trade in services.

\section{CONCLUSION}

The message of this paper is that there is tremendous scope for Turkey to benefit from adopting and implementing the legislative, regulatory and institutional framework of the EU telecommunications sector. This will lead to an increase in competition in the Turkish telecommunications sector, lowering telecommunication prices from their pre-reform levels by about 33.5 per cent, which in turn will lead to an increase in the GDP of society by 0.428 per cent. Thus the adoption and implementation of the legislative, regulatory and institutional framework of the EU telecommunications sector is expected to generate considerable benefits for the economy.

\section{REFERENCES}

Albon, R., A. Hardin and P. Dee (1997), Telecommunications Economics and Policy Issues, Industry Commission Staff Information Paper (Canberra: Productivity Commission, Commonwealth of Australia).

Boylaud, O. and G. Nicoletti (2000), 'Regulation, Market Structure and Performance in Telecommunications', Economics Department Working Paper No. 237 (Paris: OECD).

Dee, P. (2003), 'Services Trade Liberalization in South East European Countries', Paper prepared for OECD South Eastern Europe Regional Programme 'Forum on Trade in Services in South Eastern Europe' (Paris: OECD).

Hoekman, B. (1996), 'Assessing the General Agreement on Trade in Services', in W. Martin and L. A. Winters (eds), The Uruguay Round and the Developing Economies (Cambridge: Cambridge University Press).

International Telecommunications Union (1998), Telecommunications Reform (Geneva: ITU).

and assigns a numerical score to each category: (i) if no restrictions are applied for a given mode of supply in a given sector, a value of 1 is assigned, (ii) if no policies are bound for a given mode of supply in a given sector, a value of 0 is assigned, and (iii) if restrictions are listed for a given mode of supply in a given sector, a value of 0.5 is assigned. Since there are 155 non-overlapping service sectors in the GATS classification list, and for each sector there are four possible modes of supply, a total of 620 such openness/binding factors exist for each member country. Using these factors, Hoekman calculates frequency ratios to approximate the relative degree of restrictiveness of market access barriers to services trade across countries. He then establishes a judgemental set of benchmark tariff equivalents for individual sectors to reflect the degree to which market access to these sectors is restricted. He assigns a value to each country and sector using the benchmarks multiplied by the calculated frequency ratio. Thus, if the most restrictive country worldwide had restrictions equivalent to a 50 per cent tariff, then a country with a 0.9 frequency ratio would have a tariff equivalent of 45 per cent (i.e. 0.9 times 50). 


\section{ERKAN AKDEMIR, ERDEM BAŞÇI AND SÜBIDEY TOGAN}

Kimura, F., M. Ando and T. Fujii (2003), 'Estimating the Ad Valorem Equivalent of Barriers to Foreign Direct Investment in the Telecommunications Services Sectors in Russia', Unpublished paper (The World Bank).

McGuire, G. and M. Schuele (2000), 'Restrictiveness of International Trade in Banking Services', in C. Findlay and T. Warren (eds.), Impediments to Trade in Services: Measurement and Policy Implications (London: Routledge).

Organisation for Economic Co-operation and Development (2005), OECD Communications Outlook (Paris: OECD).

Stern, R. M. (2002), 'Quantifying Barriers to Trade in Services', in B. Hoekman, A. Mattoo and P. English (eds.), Development, Trade and the WTO: A Handbook (Washington, DC: The World Bank).

Warren, T. (2000a), 'The Identification of Impediments to Trade and Investment in Telecommunications Services', in C. Findlay and T. Warren (eds.), Impediments to Trade in Services: Measurement and Policy Implications (London: Routledge).

Warren, T. (2000b), 'The Impact on Output of Impediments to Trade and Investment in Telecommunications Services', in C. Findlay and T. Warren (eds.), Impediments to Trade in Services: Measurement and Policy Implications (London: Routledge).

World Bank (2005), World Development Indicators Online (downloaded on 28 October). 